\title{
Authorial Reading: Action Research in Pedagogical Reality Josef Nota
}

\begin{abstract}
:
In a narrative way, the article presents the background of the events that led to the inclusion of the discipline of authorial reading in the teaching of a particular lower basic school. The initial assumption is that authorial reading can be a suitable alternative to the development of key competencies in addition to the practice of stylistic units. Based on the obtained data, the main goal is to formulate one's own pedagogical experience at the school during an eightyear practice with authorial reading. The secondary goal is to use case studies to illustrate the ways in which specific students (and parents) can approach authorial reading.
\end{abstract}

Keywords: narrative research, pedagogy, authorship, personality, authorial reading, dialogue, school

\section{Research of Experimental Drama and Authorial Reading}

Authorial reading was created as a psychosomatic discipline designed for the possibility of personal development of DAMU students in Prague (together with the integrating discipline of dialogical negotiations with an internal partner). In the field of pedagogical training of future teachers, V. Švec, S. Suda, and M. Matějíčková, for example, mention the specific contribution of psychosomatic disciplines in their works. ${ }^{1}$

In the years 2005-18, the discipline of authorial reading was a part of personal development in the study course učitelství pro národní školu (Teaching for National Schools) at the Department of Pedagogy and Psychology, Faculty of Education, University of South Bohemia in České Budějovice. Currently, with other subjects, it is the basis of personal education in the study course Leisure Time Education at the Department of Education, Faculty of Theology, University of South Bohemia in České Budějovice. Research data are continuously published. ${ }^{2}$

The basic methodological basis for the study of authorial reading is a systematic, longitudinal research of experimental drama. The study of experimental drama is based on the premise that personality can be developed in dramatic play situations. These require (just as pedagogical situa-

1 Cf. Milena MATĚJÍČKOVÁ, Josef NOTA and Stanislav SUDA, Observing Qualitative Changes in Psychosomatic Condition, The New Educational Rewiew 2/2011, pp. 147-161.

2 Cf. Josef NOTA and Stanislav SUDA, Hledání společných znaků reflexí dialogického jednání, in: Podpora zdravého psychického vývoje $z$ aspektu ditěte a učitele, ed. Jiří JOŠT, František MAN and Alena NOHAVOVÁ, Praha: Eduko, 2013. 
tions) conscious, creative, reflected action in a 'now and here' situation. Qualitative methodology procedures have proven successful in data collection. It is mainly the gradual writing of a story about looking at phenomena in the experimental dramatic situation and beyond it. Up until now, there are stories based on dozens of case studies which have been realised for several years, hundreds of professional case studies, and thousands of written self-reflections. ${ }^{3}$ The core of the narrative approach is the focus on the partial, personal, unique experience of the participant. Meaning is generated by the participant. He connects various aspects of his life into a story. ${ }^{4}$

\section{Research Problem and Research Questions}

The intention arose on the basis of the current situation of school practice. Authorial reading in the environment of a small school has not yet been studied: the aim of this article is to reflect upon the pedagogical experience with authorial reading in the environment of a lower basic school (6-11 year olds).

With regard to the aim of the study, the main question is: What is the current pedagogical experience with the discipline of authorial reading in the environment of a small school with multiple year-group classes?

In accordance with current practice of qualitative research ${ }^{5}$ the formulated secondary question is: How will specific students (and parents) approach authorial reading?

\section{Design and Research Method}

The approach to research is driven by an effort to gain an integrated view of contextual logic. The main research question is answered by a qualitative approach as the asked question seeks to gain in-depth insight. This is done by describing cases, and by revealing some not entirely clear phenomena. ${ }^{6}$

The approach is based on procedures: 1) action research, as the topics are related to pedagogical practice, the research process is a process of learning and change, and, in addition, research with practice goes hand in hand; and 2) narrative research, which is a way of the explorer's asking an individual about his problem. Narrative research has become an integral part of qualitative research. At the same time, the researcher builds a comprehensive, holistic picture, analyses words and more extensive verbal and nonverbal units of meaning, captures the detailed opinions of participants, and conducts studies in natural conditions. Čermák points out that while the researcher loses expert status, validity, representativeness, simplicity, objectivity, determinism, etc. in this type of research, he on the other hand acquires complexity, heterarchy, indeterminism, and others. ${ }^{7}$ In addition, the research will be enriched by the possibility of sharing, participatory-dialogical interpretation, and the credibility of the findings. The narrative mode is based on a convincing representation of life experience. ${ }^{8}$ A specific type of case study was also chosen to serve as the research strategy, as the research concerns situations in which we ask the questions 'How'

3 Cf. Stanislav SUDA, Experimentální dramatika, České Budějovice: Nakladatelství Jihočeské univerzity v Českých Budějovicích, 2017, pp. 227-238.

4 Cf. Ivo ČERMÁK, Myslet narativně (kvalitativní výzkum „on the road“), in: Kvalitativní výzkum ve vědách o člověku na prahu třetího tisíciletí, ed. Ivo ČERMÁK and Michal MIOVSKÝ, Brno: Psychologický ústav, 2002, pp. 19-25.

5 Cf. Roman ŠVAǨÍČEK and Klára ŠEĎOVÁ, Kvalitativní výzkum v pedagogických vědách: Pravidla hry, Praha: Portál, 2007.

Ibid., pp. 69-71.

Cf. ČERMÁK, Myslet..., pp. 11-25.

Ibid., p. 16. 
and 'Why' certain phenomena happen, and over which we have only limited control. ${ }^{9}$ These are certain unique cases that have been deliberately chosen to represent: a) the pupils' relationship to the discipline of authorial reading; and b) the possibility to reflect on the specific method of pedagogical intervention. The collection procedure had to be revised several times (for case studies of specific pupils, it was necessary to verify the validity of the observational data by the process of using other data, for example, to obtain statements from the pupils' parents.)

The disadvantage was that the data from the case studies (due to the scope) had to be abridged for the purposes of this article, which reduces the complexity of the resulting picture.

The names of the children were changed to preserve the ethical side of the research. The course of the research was governed by the conditions of the field and was, at its core, participatory.

\section{Research Data}

The data are based on narrative interviews, participatory observation (especially field notes and a pedagogical diary), unstructured interviews with pupils and their parents, mass discussions with pupils, content analysis of authorial texts, and unstructured, in-depth interviews with schoolteachers (school headteacher, two teachers), and case studies.

\section{Research Quality and Interpretation Issues}

Triangulation was used not in the context of efforts to strengthen the validity of the collected data (by placing two different methods against each other) but in the second sense, that is, as a strategy to support knowledge (by obtaining additional information). ${ }^{10}$ Participatory observation, narrative interview, and interpretation of data obtained from colleagues were used to support the findings. ${ }^{11}$

\section{The Beginning of the Story}

The small village school in southern Bohemia where I am a teacher currently has (thanks to the extensive reconstruction of the fourth classroom) 35 children and four permanent teachers. Since 2020, the building has also included a kindergarten. However, when I joined in 2010, the situation was somewhat different. At that time, the school was attended by 12 children. There was only one class and two teaching staff (myself and the school headteacher who had joined the year before me). The starting conditions for my first real teaching practice were dramatic. The (then still) one-class basic school had a desperate shortage of children (even the local people preferred to send their children to other schools in the area). The reputation of the school was in a deplorable state and its school curriculum was formally copied from another school.

Our entry situation was described by the school headteacher as follows: 'I was alone in this school and I had just started, we fought against closure. We started with a small number of children. We didn't know at all what we were doing pedagogically, but we did what we were able to. It helped us tremendously then that our school was discovered by parents who wanted a free alternative in the area for their children. And that was small-class education with the opportunity to discuss decisions a little bit (simply, to have a school with a functioning school board). The fact that we have some

9 SVAŘÍČEK and ŠEDOVÁ, Kvalitativní..., p. 105.

10 Ibid., p. 203.

11 Cf. Michal MIOVSKÝ, Kvalitativní prístup a metody v psychologickém výzkumu, Praha: Grada, 2006. 
prestige was known to us with great delay (we got the information from the school inspection). Until then, I thought that we were just discussing ideas about education with parents (which were identical with mine). A positive evaluation from the school inspection revealed the fact that our pedagogical attitude has some support in the Czech school system.

With the arrival of new children from the surroundings, we began to grow pedagogically. Especially the smarter children inspired us to form basic pedagogical attitudes. The point was that we gave them space to learn and support. Then it was interesting to observe how they managed the study material without us and to estimate where they needed help. But we wanted to limit our help so that students activities were not interfered with by adults. For example, we did not want them to work strictly according to thematic plans as these are not completely binding in the pedagogical process (it is only a key curriculum for teachers so that they do not get lost in pedagogical intervention and have some lead). It was absolutely crucial for us to watch a particular child approaching the expected outcomes in the $5^{\text {th }}$ year in an original, individual way. Our principle of pedagogical intervention has become an individual approach in the sense of developing the whole person, supporting weaker students in the area of school results, and protecting them from repeated experiences of failure, not hindering talented students by anything and anyone. The idea has become and remains a happy child. For the school, fundamental questions were how to make the pupil competent in the school environment to such an extent that he will need teachers less and less in the sense of direct intervention (for interpretation, command, instruction). That we will rather find a dialogue together.'

During unstructured interviews with the school headteacher, I realised that we probably experienced the maximum of pedagogical freedom and the resulting responsibility for the consequences of pedagogical interventions for the first time at our pedagogical beginnings. It should be noted that the vast majority of pupils had almost zero motivation to do schoolwork at the beginning. Some of them had reduced study prerequisites as well. The initial inhospitable conditions proved to be very advantageous. They encouraged my colleague and I to formulate basic ideas in a flash. These ideas became the framework of formal documents (School Educational Programme - ŠVP). From the very beginning, I was in charge of (in addition to other subjects) the management of 'stylistic education' for pupils in the $3^{\text {rd }}, 4^{\text {th }}$, and $5^{\text {th }}$ classes $(7$ children, approximately $8-10$ years old) at the mentioned school. Within the emerging pedagogical ideas, I tried an experiment with authorial reading.

\section{Problems of Stylistic Works}

When beginning this, I had no real pedagogical experience with style and communication education. I had a vague idea that there is an educational area in the RVP (Framework Education Programme) called 'language and language communication'. In this area, the student's goal is to acquire knowledge and skills applicable in practical life situations (he should become linguistically competent - grammatically and in writing).

When reading the common methodologies in textbooks for lower basic schools, I found the fact that in spoken and written expression, the emphasis is more on mastering the basic stylistic units ('narration' and 'description') than on the development of the aforementioned competencies. In the methodological materials, simply said, it is primarily an exercise at first. Pupils acquire the basic language resources for working with the curriculum and reproduce simple texts. What is called a 'style exercise' is a rather marginal issue in textbooks. Its realisation (rehearsal) usually starts in the $2^{\text {nd }}$ grade, precisely through 'stylistic exercises' (stylistic exercises are further divided 
according to the methodological goal into inventive, compositional, stylistic, etc.).

At lower basic schools, pupils most often encounter supplementary exercises, for example: 'What was Snow White like? Choose the appropriate words from the menu and then write (...) Snow White was as beautiful as... Her hair was as black as... Her skin was as soft as... Her eyes were... and her mouth was... Use these words: silk, fairy, raven, charcoal....' ${ }^{12}$

In the textbooks of the older date of publication, stylistic exercises are realised by various 'changing' types of examples, for example, to translate the text into the past. In current methodological texts, 'changing' examples no longer appear so often because their contribution to the cultivation of language skills is - at the very least - questionable.

We can also mention substitution exercises ('Replace the following words with synonyms in the text: they are inserted, rotated, removed, fade, maybe, serve' $)^{13}$ or model exercises, that is, explicitly, it is an imitation ('Create exercises about winter according to formulas: V1 but V2, V1 because V2, V1 because V2 and V3. ${ }^{14}$

At the end of this methodological journey (from the $4^{\text {th }}$ year of lower basic school), 'stylistic exercises' are traditionally studied. These exercises are defined by the authors of the materials as a space for the pupils' own invention. Pupils have the opportunity to work independently in the creation of not only sentences but also whole units. The task is connected with the creation of the text outline, the inclusion of direct speech, and with respect for the rules of the stylistic unit that is being discussed. Personally, I think that the designated space for student invention is somewhat overestimated there as stylistic exercises are again closely connected with the practice of formal stylistic requirements, for example:

1) Which sentence units would you mark as the introduction?

2) Which sentence units do you consider to be the conclusion?

3) How would you call the part between the introduction and conclusion?

4) Can this part be more divided?

5) Build an outline of the entire narrative.

6) In the text, notice the sentences followed by exclamation marks - that is, exclamation sentences. Find examples of such sentences and read them with the right intonation. ${ }^{15}$

At middle schools (15-18 year olds), the same goal is usually pursued: to train the student in functional stylistics, that is, in the creation of stylistic units (description, interpretation, reflection, report). It is assumed (sometimes erroneously) that the student masters the appropriate stylistic procedures in practice - that is, when writing texts. ${ }^{16}$

In general, any training develops a developmentally lower personality structure of an individual than procedures requiring one's own creation, imagination, and divergent thinking. However, the aforementioned methodological structure can not only limit thinking, but also provide safety, especially for younger students. Following the structured methodology of the aforementioned textbooks is therefore safe for both the pupil and the teacher. The pupil knows what is expected, and the teacher is not worried about what he wants from the pupils. In addition, there are objectives for evaluation in the textbook template.

12 Eva HOŠNOVÁ, Český jazyk pro 2. ročník ZŠ, Praha: SPN, 2006, p. 82.

13 Jaroslava KOSOVÁ, Český jazyk - učebnice pro 3. ročník základní školy, Plzeň: Fraus, 2009, p. 50.

14 Ibid., p. 75.

15 Rudolf ČECHURA, Hana STAUDKOVÁ and Miroslava HORÁČKOVÁ, Český jazyk pro 4. ročník, Praha: Alter, 1996, p. 15.

16 Cf. Zbyněk FIŠER, Tvưrčí psaní, Brno: Paido, 2001, p. 29. 
However, it would be worthwhile for some relevant research to trace the implicit concept of style teaching, and the perceived 'higher quality' in the texts seen by the teachers (as the student is trained in functional writing and receives 'style tools' methodically. In essence, we anticipate (and sometimes rightly) that a student does not have (and initially cannot have in a greater amount) an aesthetic feeling. But everyone should be able to write a 'style unit. Therefore, training lies, in fact, in mastering the basic hints that the individual follows when writing from the beginning. Since these hints relate to the structure of writing, this structure also leads to thinking (this is a convergent way of solving problems). Therefore, it should not be entirely upsetting for anyone when a group of students - independently - write a very similar work. This leads to a phenomenon that teachers at basic school know very well (this concerns teachers of Czech language when they have to correct graduation theses as well).

It is quite possible that the student will 'find' himself when practicing stylistic exercises, and that originality, individuality, and invention will somehow pop out through these exercises. The pupil can (should) 'plant' something of his own in the acquired procedures. He will become the author. Authorship can be that quality, and prototypes of 'style units' will disappear from the classes. I believe that a potential critique of the approach requires caution: the process probably does not depend on the methodology only, but also on the way the teacher works with the methodology. The space given to students with creative potential by the teacher is crucial for the development of creativity. ${ }^{17}$

In the curriculum of our school, the study course of Czech language and literature is a part of the educational area 'language and language communication'. The content of the educational study course of Czech language and literature has a complex character. For clarity, it is divided into three components: communication and style education, language education, and literary education. In teaching, however, the educational content of the individual components is intertwined. In the process of creating the curriculum, the foundation (among other things) was the following educational strategies aimed at developing key competencies:

- independence, organisation of one's own activity;

- own judgment, initiative, creativity, responsibility;

- communication skills, cooperation, teamwork;

- learning about one's own possibilities;

- presentation one's own results;

- personal experience;

- transition from frontal teaching to activating methods;

- practical exercises;

- observance of communication ethics (objectivity, listening, space for different opinions, respect for original, unsuccessful, etc., opinions);

- the premise of coming to know oneself and relationships with others.

When creating ŠVP, I argued with the school headteacher about whether the time we spend practising and mastering stylistic units at the elementary school will:

1) respect the set educational strategies;

17 Cf. Josef NOTA, Experimentální dramatika: Autorské čtení u žáků na 1. stupni, in: Perspektivy výchovy a vzdělávání v podmínkách současného světa, ed. Miriam PROKEŠOVÁ, Ostrava: ČPDS, 2017, pp. 89-94. 
2) be genuinely aimed at developing in particular (a) learning competencies, and b) social and personal key competencies (working with a text; formulating one's own opinion; critical thinking; reading comprehension and working with text; using pupils' interests; forming one's own opinions and their presentation; appropriate communication with classmates, teachers, and other adults at school and out of school; discussing and listening to the opinions of others).

For these reasons, we decided to include authorial reading as an alternative approach to communication and stylistic education.

In the following chapter, in order to understand the context, it is necessary to introduce this discipline theoretically, and specify its two main differences from 'creative writing'.

\section{The Phenomenon of Authorial Reading}

In the 1990s, 'creative writing' or 'authorial writing' began to be promoted in the Czech Republic. These terms can evoke authorial reading but they are different. With great simplification, we can say that creative writing is primarily focused on the artifacts in art. The path to this artifact is externally controlled by the application of methods or techniques: that is, through the work procedures and instructions for creating texts in the given areas. ${ }^{18}$ The primary goal of creative writing is the aesthetic quality of the text although formative influences on the personality of the author of the text are also taken into account. Part of creative writing is self-reflection. Unlike authorial reading, however, it is purposeful and has a predetermined goal. The aim of self-reflection is to evaluate the process in creative writing. In the philosophy of creative writing, creativity is a feature that can be technically developed especially by the heuristic techniques focused on individual stages of problem solving and their development. ${ }^{19}$ Concerning the approach, creative writing is similar to drama education in the Czech environment. ${ }^{20}$ Creative writing was created with drama education at a similar time and both methods are influenced by the same behavioural approach to the individual (personality can be formed from the outside methodically and technically).

Authorial reading differs from traditionally understood stylistic education and from creative writing primarily due to the fact that it does not view students through the behavioural approach. Behavioural pedagogical tendencies explain the dynamisation of an individual's inner strength by a mechanism: task $\rightarrow$ success $\rightarrow$ appreciation. ${ }^{21}$ In this view, pedagogues are understood as 'strategic managers' who assign a task: a specific (educational) goal which should be evaluated (according to various interchangeable criteria). Success in school situations is taken as the main motivating factor. It gives students the confidence to repeat the activity and make a performance according to the specified parameters. However, the behavioural view of the issue of pedagogical activity is not broad enough at a time when the pedagogical emphasis is not on performance as such (quantitative value), but on the development of such talents of pupils which are subject to qualitative criteria. Typical (although somewhat thematically profaned and vague) is the declaration of a pedagogical focus on pupils as such (on their personality), that is, not on their progress

18 Cf. FIŠER, Tvưrčí..., pp. 25-35.

19 Pavla PAZDERNÍKOVÁ, Tvưrči psaní a vědecká práce. Brno, 2009. Dissertation. Masaryk University. Faculty of Arts. Department of Information and Library Studies. Thesis supervisor PhDr. Zbyněk Fišer, Ph.D., p. 29.

20 For example, Eva MACHKOVÁ, Metodika dramatické výchovy, Praha: IPOS ARTAMA, 1999; Josef VALENTA, Osobnostní a sociální výchova, Kladno: Aisis, 2005.

21 Cf. Geoff PETTY, Moderní vyučování, Praha: Portál, 1996, p. 40. 
(visible, measurable behaviour). The focus on the development of pupils' personalities has become the subject of many approaches that significantly affect the pedagogical reality (for example, in the form of drama education or ethical education: disciplines and methods that are conducted as complementary to the educational study course of RVP).

The aforementioned behavioural (pedagogical) approaches are very close to role theory. Their specific feature is that their concept usually reduces the individual's personality to ways of behaving and experiencing (in these ways, the individual expresses his idea of what corresponds to expectations related to certain life positions and situations). ${ }^{22}$ According to Drapela, in the view of personality psychology, it would be the external frame of reference for the study of behaviour. It allows the measurement and evaluation of behaviour as normal (coveted) or abnormal (personality maturity is understood in terms such as 'social adjustment'). However, personal freedom of the choice is significantly limited by factors (external or internal). ${ }^{23}$

Authorial reading is contradictory in its conception to the abovementioned. Philosophically, it is close to humanistic theories of personality in which no significant restriction of personal freedom and choice by external or internal factors is proclaimed. A personality is the author of its deeds: a person is a personality (to a corresponding extent) if his actions are based on himself, if they express his knowledge, his experience, his skill and are not just mechanical imitations, copies of a model. ${ }^{24}$

The second main difference is that the authorial reading is not primarily about a 'nice text' but about discovering the message 'through the text' for the reader and the viewer in a specific situation. It is therefore primarily a matter of the individual's own ability to discover (and apply in a meeting with others) his creative potentials and to thematise his own message.

V. Fryntová explains the paradox of authorial reading accurately: the mere reading of an author's text does not guarantee that the author is communicative in relation to the listeners. This is not primarily about the genre quality of the text, nor the technique, but about the idea concerning the read text:

\begin{abstract}
How strange. After all, perhaps the author knows what he wrote, what he said, where it was. It is all clear to him but we listeners of authorial reading usually do not hear that. How is that possible? A possible explanation is that the author has already written the text. It feels like he threw everything away, knowing that he is done. He does not think at all about the fact that when he was writing the text in his slum with his feet up, he was experiencing all this more intensely than any actor! After all, he could not write it if he did not have that idea. He just does not feel that idea right now. (...) The paradox of authorial reading thus shows us that reading requires more than understanding the text, understanding the author, or understanding the meaning of the message. ${ }^{25}$
\end{abstract}

The discipline of authorial reading is quite wonderous. It is so in the fact that the artifact created from stylistic structures is a secondary phenomenon. The primary quality is the author's ability to give a message about a particular text. The core of authorial reading is therefore not writing but reading: the situation created by the author between him and the listener(s) which is the basis for dialogue (dia-logos, understanding 'through the word, meaning').

\footnotetext{
Cf. Vladimír SMÉKAL, Pozvání do psychologie osobnosti, Brno: Barrister a Principál, 2007, p. 33.

Cf. Victor J. DRAPELA, Přehled teorií osobnosti, Praha: Portál, 1998, p. 158.

SMÉKAL, Pozvání..., p. 33.

25 Vítězslava Ada FRYNTOVÁ, O paradoxu autorského čtení, in: HIC SUNT LEONES (O autorském herectví), ed. Michal ČUNDRLE, Praha: AMU, Ústav pro výzkum a studium autorského herectví při katedře autorské tvorby a pedagogiky, 2003, p. 67.
} 
To cultivate authorial texts, it is therefore necessary to verify the texts publicly. So far, we have managed to reflect upon the long-term experience with adults, especially with students of pedagogical disciplines (I hereby refer to the articles by S. Suda who summarised the data obtained from students from the University of South Bohemia within the long-term study of experimental drama).

The realisation of authorial reading with adult listeners has simple rules: a group of students read and comment on their texts in a non-evaluative way. The students thus pay attention to the author of the text. They help him discover a personal topic through his own text on the basis of public attention. In this way, he can look for the necessary aspect in it - the ability to tell a message. The initial assignment within the courses is absolutely without rules for students. 'Write what you want, the length of the text, the form, and the genre is entirely up to you.' Adult students brought up in the rules of stylistic procedures are usually completely dismayed by the freedom that is offered. It is repeatedly confirmed to us that a certain structure gives safety - some students prefer to choose the classic 'stylistic work' (introduction; body; conclusion) or say that without a specific assignment they have nothing to write about and that such a task is difficult for them. In their attitudes, they also express irritation due to ambiguity. ${ }^{26}$ But over time, the all-encompassing fear usually disappears, and students discover interest: the activity itself becomes a driving force for further attempts.

It was clear that if one wanted the successful transfer of the discipline of authorial reading to the basic school environment, younger school-age pupils would require a different approach than the one which had been used for university students.

In the following chapters, I will therefore try to describe how the basic principles of the mentioned discipline were successfully transferred to the environment of a basic school (as a certain alternative to communication and style education). The results will also be introduced.

\section{Discovering Authorial Reading at Basic School}

As already stated, the basic instruction of authorial reading is open, that is, the topic, the scope of the text, the content focus, or the way of using stylistic means are not ordered. Then the text is read to other listeners. Based on the attention of others, the author of the text learns what qualities his text has. Based on the experience of this public reading, students then formulate written self-reflections. These then help them to map their study path.

The common practice of primary schools is that communication and style education is taught randomly according to the thematic plans of teachers, or in blocks. When creating ŠVP, we wanted authorial reading to become an integral part of the weekly schedule.

I soon found that the developmental characteristics of younger school-age pupils does not allow basic instruction to be completely open. Therefore, we carry out the authorial reading in the primary school environment as follows. At the end of the school week, students have the opportunity to come up with topics that fascinate them. My role is to make the ideas for the texts: 1) thematically open enough to awaken imagination and desire to write; 2) originate exclusively from children's ideas; 3) undergo pedagogical correction only if their potential is ethically, morally defective.

26 As part of the qualification work, (Josef NOTA, Dialogické jednání jako možnost rozvoje osobnostních dispozic učitele. České Budějovice, 2014. Dissertation. University of South Bohemia in České Budějovice. Faculty of Education. Department of Pedagogy and Psychology. Thesis supervisor doc. MgA. Stanislav Suda, Ph.D.) the research showed that the fear of ambiguity in the assignment was a typical factor in the personality preparation for the teaching profession for graduates of middle pedagogical schools (15-18 year olds). 
For the first two years of authorial reading, I let the children vote for one common topic from the offered written options. However, based on interviews with parents, I found out that children who are voting for a different topic and then having to submit to the topic with the largest number of votes do not write texts with joy and interest. Therefore, it was very useful for me to leave the choice of a specific topic from the list to individuals. Most 'advanced' students already 'have their own way' and their own topic, regardless of the 'official' topics (which were formulated together). They use the offered authorial freedom to continue the stories. Thus, children create whole chapters which follow each other thematically.

Even in the primary school environment, emphasis is placed on the idea that the basis and the very core of such meetings is not the written artifact itself (intended for evaluation by the teacher) but a public reading out loud. The goal is to learn to listen to the other, to ask additional questions. The authors of the texts learn to respond to supplementary questions. The activity itself is a source of the development of the listener's and reader's ability to give a message, to express oneself.

Authorial reading takes time. In our case, a group of 12 children needs at least two consecutive teaching units for a concentrated meeting. However, these are also further divided into 'rest time' diversified by other activities (e.g., singing original songs) as it is empirically known that children of younger school age are not able to maintain full attention during the entire formal teaching unit.

When there were fewer children at school, I motivated students who have not yet read to try their first authorial work. They talked about the selected topic orally. They also drew pictures in a notebook (as support for their ideas), or took an artifact (toy, object) with them to school. I led these students and helped them to try to express themselves in front of others and listen to others within their possibilities - so that they would have a basis for public, authorial action from the $1^{\text {st }}$ grade onwards. After 4 years, I started practising authorial reading only with children in the third to fifth grade. The main reason was the increasing number of children in the group as the school began to grow.

As they prepare for these lessons at home, for the greatest possible meaningfulness of these meetings, I asked the pupils' parents for help using an open letter. ${ }^{27}$

27 ... Children are not evaluated for their texts as marks cannot express the quality of the texts (e.g., Božena Němcová got As, Alois Jirásek got Bs). If they get a mark, it is meant only as a motivational thing ... Our common task here, at primary school, is to arouse children's interest and confidence. We want to show them that they can write (and formulate their own ideas in front of others). A talented child can become a writer. A disappointed child, or a child without interest can create a relationship with language, literature, and reading in a safe environment. ... A student who does not have this confidence, i.e., who does not believe in his ability, will not be able to write such a text. In this way, I ask for great patience with children. I also test my patience during our classes. If you write and dictate a text to a child, it was you who have mastered the task, not the child. It is clear information for him in the future. He thinks that his work is insufficient and that he will need you next time. Then you find yourself in a vicious circle. You stress yourself every Thursday night because the teacher 'came up with some stupid nonsense' and your child has to write it right in order to 'make the teacher happy'. This should be, of course, taken with a detached view ... But that is not the point. We don't want the text to be 'nice'. We want children to write it themselves as this moves them forward. Then it is worth it... How to do it? At first, a child can be really unhappy about paper, especially if he does not believe that he can write something without help. Our common task is to encourage him and give him confidence. He may write three sentences at first which is great (given that he has not written anything at all before). I strongly recommend not to bother the child with blank paper. We should 'talk to him first" using questions which are aimed at the topic (completely naturally if possible). He will formulate something - let's not worry about it at first. In the case of these texts, we should not put our own thoughts into the child's head. For example, there is the topic 'If I were on Mars'. If we say that aliens is a nonsense invented by lunatics and that they do not exist, the child repeats our words and put them into the text. Within the above mentioned, though, it will not give him anything. We closed the topic for him. What we should do is encourage him. Children should write what they think. Their thoughts can be based on parents' views but the aim is not to argue about the existence of aliens. We are talking about a literary, authorial, child-invented text that may not correspond to the truth. Alois Jirásek also wrote O králi Ječmínkovi (King Barleycorn) and J. R. R. Tolkien invented a whole fictional world. For the future, it is necessary to mention that we are not satisfied with this 'free writing' only. In case of advanced students, we will continue the dialogue with you, the parents, and we will agree on how to develop your children's creativity in this area the best (...). 
For this type of experimental teaching, it was absolutely crucial to gain the support of parents: the repeated dialogue with parents about the philosophical background of the authorial reading and about the overall benefits was important. However, some parents repeatedly tell me their concerns: "Will they not miss the practice if they do not practise "storytelling" and "characteristics"...?' However, this is not the case: the fact that we do not engage in the training of stylistic units primarily does not mean that we completely neglect them. However, it is usually advantageous if the basis for the explanation is an authorial text. Using such a text, a specific stylistic formation can then be easily described.

In the following chapters, a reflection upon the experience of authorial reading (finding the answer to the main research question) will be illustrated with the help of case studies.

\section{Example no. 1: a bright, quirky child with excellent school results}

Pedagogical observation: He has been completely independent since the $1^{\text {st }}$ year. During his years at our school, he has organised schoolwork on his own initiative (within a school with multi-year group classes, it is necessary that some pupils always work independently while the teacher concentrates on another group, for example, by giving an explanation of a new topic). He has had excellent results. Within our school with multi-year group classes, there is an emphasis on supporting the learning of younger children by older children (5th year pupils tutor, for example, $2^{\text {nd }}$ year pupils). During this 'teaching' activity, Martin lacked the necessary patience. However, he did not actively build relationships with others, he put no real effort into being sociable. He was very popular in the group of children, and with the pedagogical staff as well (statement of the headteacher: 'I probably miss him more than he misses me.). He was admired for his sports achievements. His mother evaluates him as unnecessarily confident, and not very hardworking ('You may not see it at school, but he does not do anything at home, he does not learn, he does not prepare, he just hangs around.') He has a quirky, ironic sense of humour.

He left the small-class school a year ago with excellent results. He continues his studies at a grammar school, entering it at the earliest opportunity.

If the discipline of authorial reading can be considered a specific possibility for one's own experiment, Martin has undoubtedly made the most of this possibility.

He has been one of the main initiators of new topics since the $3^{\text {rd }}$ year. At our school, his reading almost immediately gained lasting popularity among his classmates for his playful theatricality. He 'seated' all his texts in a specific voice (he used a particular breathing technique) and then read wholly without any rising or falling intonation. (The headteacher: 'When I heard you reading, I was ecstatic. But when I heard Martin, I was amazed. It was the ultimate comedic performance as he read such interesting text so annoyingly. Everyone listened to him the whole time. He just kept his style.')

After about a year of authorial reading, Martin found out that his 'ordinary authorial texts' (thematically focused, with a clear storyline, well-pointed) ceased to satisfy him and began to destroy his previous authorial style. For example, he wrote three long sentences, stretching the vowels of the words. These were in fact 'textual and reading excesses' but, with all the expressiveness of Martin's performance, they became extremely popular. And, of course, it was copied by other classmates. After a few months, Martin's mother called me. She was worried that Martin's writing lacked any of the quality of his previous work ('He only writes garbage, I'll probably kill him for it.'). I suggested waiting. After another two months, the original theatrical fads disappeared. 
Instead, Martin discovered that more decent texts and performances gave him more opportunities. He could make his drama more variable. In fact, he began to feel the need to write stories with a strong point. It is not possible to do this while being a clown.

Martin showed me: 1) what the advantage of authorial reading is in the moment when there is a 'dynamic presence': someone who inspires others to discussion, who is original, communicative, and encourages creative group dynamics; 2) possible predictable development that authorial experiments may have.

Thanks to Martin, I realised that the core of authorial reading is not in the instruction that children follow. The core is the situation that children create for others by their reading. Martin was excellent at this: he had a talent for creating, he was motivated, and when I was able to manage his naturally ironic sense of humour (which was difficult to digest, especially for younger children), he co-created a welcoming atmosphere without barriers of false emotions.

\section{Example no. 2: experience with a child who has a negative experience from a previous school}

Evicka (9 years old) comes from a family with both parents and 4 other siblings. The parents' statement follows. The parents placed Evicka in our school at the age of 8 . They justified the need to change the school by saying that Evicka was unhappy at the previous school-her former class teacher overloaded Evicka and criticised her for unimportant things unjustifiably. As a result, these pedagogical demands led to the fact that Evička began to somatise (she was ill as often as every month). She has been in our school for two years; she likes authorial reading (according to her statement). Currently, due to anti-pandemic measures, she misses meeting children while reading authorial texts.

Evicka is an extrovert in her speech, she communicates with adults without difficulty, she is proactive and a leader when playing with children. She is very active in schoolwork but she is not particularly motivated by her performance.

When Evička became acquainted with authorial reading, she initially (and repeatedly) needed to make sure that she could really write freely, in her way ('What if I get it wrong?'). Her first texts were guided by a conventional structure (introduction, body, conclusion). After the third authorial reading, the main character of Simona appeared in Evička's texts. Little by little, she made her the main heroine of other texts. After a year of writing, she continues with a kind of 'novel writing' in which Simona experiences an extraordinary adventure. Currently, the chapter about the little girl Simona (which has been prepared by Evička for the authorial reading meeting) has a length of about 3 pages of A5 manuscript.

Her reading is very expressive, loud. She is looking forward to every meeting. When Evička gives feedback to her classmates, she is overly critical and presents content alternatives to the content of the read texts ('I would write it differently...'). She is excessively critical of her own texts.

When I asked Evička to tell me about her relationship to authorial reading, her statement was dominated by a comparison of her former and current schools:

Evicka: When I was in my last school, I did not enjoy writing stylistic works because we only had it (the subject) sometimes. And we always heard that we could not do it and that we wrote it too long. And we could not say what we wanted at all. When I started the new school, these things changed. And I started having fun. Much more.

Me: But what does 'we could not say what we wanted' mean?

Evička: Simply - when I wrote something, I had to complete it (assignment). I had to write it during 
the class. And when we did not have it the way the teachers wanted it, we just got an $F$ and they (teachers) did not care what we wanted.

Me: And did you read your texts to each other?

Evicka: No, the teacher just checked it and let it go.

Me: And what was checked?

Evicka: She checked it for mistakes, like spelling. And then she checked it to see if we had done it according to her assignment and so on. ${ }^{28}$

Evička enjoys the opportunity offered by authorial reading. Her case helped me to formulate how the evaluation environment and pressure on pupils (to make a pre-formulated product) can work together in order to block out the potential that children may have.

\section{Example no. 3: experience with a very anxious child}

Since the $1^{\text {st }}$ year, Pavel has shown anxiety, he has been strongly introvert. According to his mother, he has had communication difficulties since a young age. It became more apparent when he entered educational institutions. He found it difficult to tolerate criticism, and immediately responded to a possible failure by crying or escaping (hiding under a table, escaping from class, searching for shelters). He has had poor performance since the $1^{\text {st }}$ year. According to the school headteacher, the cause was low frustration tolerance. He gave up unnecessarily early when solving problem tasks, cried over tasks, and did not work. With regard to his obvious study talents, he was not evaluated at all in the first two years, he was evaluated only verbally.

The headteacher of the school: 'I think it is a miracle that we did not kill him - with bad grades and generally - right in the $1^{\text {st }}, 2^{\text {nd }}$, or $3^{\text {rd }}$ year. He was smart but, in fact, desperately emotionally immature. But then he began to manage his bouts of crying, there were fewer and fewer of them. (...) The trigger for that cry was practically anything. They also called me from ZUŠ (Elementary Art School) as to whether he and his brother had a bad family background.

In the $5^{\text {th }}$ year of school, Pavel began to have a spontaneous interest in learning. He was proactive in his schoolwork, he began to have above-average results. According to his individual plan, he caught up with everything he had missed. As the headmaster said: 'For the first four years, I was trying to reassure his parents that it would be alright. Fortunately, it went that way.'

He joined the authorial reading group in his $3^{\text {rd }}$ year. It is common for first-year children to initially write a maximum of 3-5 sentences only before they discover certainty in their expression and find out that they can dare, get into writing practice, and verify their message while reading. Pavel lasted with his three sentences the whole school year. In addition, persuading Pavel to read them aloud was difficult. Sometimes even before the authorial reading he hid under the table and refused to come out the whole teaching unit. His mother was the most desperate of all of us. She was describing to us how the preparation of the five sentences was a day-long suffering for him and how he was afraid that he would have to read his texts aloud in front of others. At the end of the $3^{\text {rd }}$ year, no development was seen - neither in the reading nor in the texts. In the $4^{\text {th }}$ year of school, Pavel discovered a strategy which helped him to avoid reading aloud: he let his classmates read his texts. I interpreted it as another of Pavel's escape strategies that I did not want to support. I did not force Pavel to read his text aloud in front of his other classmates, but I agreed with him on an alternative: he would read the text only to us, the teachers. He had no problem with that as he probably presumed support. The quality of the texts remained at a low level. Pavel formally

28 The quoted passage is from an in-depth unstructured interview with the student on $12^{\text {th }}$ June 2020. 
fulfilled the requirement only: he had something written and he had to read it to others. I did not know much about this condition - I agreed with his parents that we would leave it this way for now...

In the $5^{\text {th }}$ year, something very significant began to happen with Pavel. He came to ask me if he could show something instead of reading. He had programmed something using a computer application and he wanted to show it to other classmates on a screen. It was a trivial sketch: a cartoon character. A text bubble was formed at his mouth, music played, and the image then ended. I opened a space for discussion about Pavel's authorship as if it was a read text. And things started to happen. Pavel's classmates were obviously shocked that Pavel was active and praised him for it. Pavel did not show anything at all. For the next class, though, he brought another, similarly programmed feature. It lasted a little longer. According to his mother, he spent about 8 hours of his time working on it. His mother was mainly worried about what I would say about it and whether Pavel was not running away from the assignment again. On the contrary, there was a growing hope in me that perhaps Pavel was discovering how to adapt the assignment. Honestly, in essence, nothing could be lost - before the mentioned screening, Pavel was very far from the goal and meaning of authorial reading. After about a month of using the programmed characters, another milestone appeared: the animated character in the program was given Pavel's head. It was an elegant way for Pavel to act on his own behalf. Around the first half of the $5^{\text {th }}$ year, Pavel's last discovery was in filming his own videos from the environment of the small town where Pavel was growing up. Pavel played the role of director, sometimes playing himself in his scenes. He made several friends who helped him with his work (they acted as actors and extras for him). He edited the recorded material himself. Then he released it and showed it to his family and to us at school during the authorial reading classes.

I have noticed that authorial reading at a young school age has a certain development: from the first unstructured, shy attempts, through conventional texts with a template structure, to experimental, inventive, personal texts. Pavel has developed as well through his type of authorial work which he discovered for himself and verified in front of others.

For me, it is a finding that the search for a way of expression and one's own work does not have to go the direct way and does not have to go through the discipline of authorial reading. There are individuals who prefer to stand behind the camera than in front of it. Pavel left our school last year. He decided that based on his experience with his alternative approach to authorial reading (where he preferred to make films as an author), his goal is to become a cameraman. So, we will see. In our last interview, Pavel's mother confirmed his decision to us: 'He also found a school and he just wants to do it.'

\section{Example no. 4: experience with a child who has reduced study prerequisites}

From the observation of the school headteacher: Marecek is a 'prayed out' boy born into a family with both parents. He has a sister who is 5 years older than him. He has been greatly favoured in the family at the expense of his older sister.

At the school enrolment, he showed signs of emotional immaturity. His parents were sensitively told about the prediction of possible learning difficulties but they wished Mareček to start school properly at the age of 6. Mareček had obvious speech therapy defects which the school almost completely remedied as part of paid speech therapy prevention at the age of 10 (until then, his parents had not visited speech therapy with him despite the school's recommendations). Since the beginning of schooling, 
the problems of the given emotional immaturity and reduced study preconditions have dominated. He understood the contents of the main subjects slowly or not at all, communicated trivially, and suffered from a weakened ability of analysis/synthesis during reading practice (within the school group, teachers worked with him using materials suitable for the prevention of dyslexic problems). The parents acknowledged the proposed possibility of diagnosing Mareček's study difficulties with a pedagogical-psychological counselling centre but they never paid a visit to this workplace. Over time, the parents began to downplay these persistent difficulties, or to look for causes in undeveloped motivational structures ('He is smart but he does not want to.').

He reacted irritably and in the group of children; he could not accept failure. During the period of compulsory schooling at the elementary school, we educators did not completely break down his bad habit of opening his mouth wide to every question asked and gaining time to answer by saying an extended 'Whaaaat?' He has been evidently physically gifted, and his father encouraged him to play football where he has had a great opportunity to experience success. An interesting thing was the transferring of the learned unethical behaviour from this collective sport to the school environment (simulation of injuries during outdoor games, being hysterical, verbally aggressive arguments about the correctness/incorrectness of the actions of others, etc.).

He left school two years ago with E grades, he is currently repeating the school year at the first level of secondary school.

Mareček joined the group of authorial reading in his $3^{\text {rd }}$ year and immediately began bringing 'stylistic units', that is, conventionally structured works in the style of introduction-body-conclusion. Mostly, it was a story with a simple point. Even though the text was written in Mareček's handwriting, Mareček struggled to decipher the message hidden in the sentences. It took him a long time to read his text which he himself did not understand at all. The discrepancy between Mareček's usual oral expression and what he had in the text testified to a strong parental intervention. Me: 'Mareček, did Mum or Dad help you?' Mareček: 'Whaaat?' Me: 'Mareček, I am talking about the text, it is written really well, it would just be nice to improve the reading so that we can understand it better. Did Dad or Mum help you with it?' Mareček: 'Both of them.'

Despite several conversations with Mareček's parents about the fact that Mareček is not classified in any way by me and that the purpose of authorial reading is not to write a nice text but a real reading (which is the subject of dialogue between children), authorial reading remained a time when Mareček could not go out and kick the ball. The protective parental preparation of texts for Mareček was analogous to the preparation of his snack for regular football training. Authorial reading was never authorial for Mareček, and, in fact, it was not even reading with the necessary qualities. The most lacking quality was probably patience (on the part of all involved).

\section{Example No. 5: experience with an emotionally deprived child}

Bertík's parents decided not to enrol their son for studies in the town school in their place of residence. The reason was the negative experience which they had when Bertik's older brother went to this city school (mother: 'We did not want Bertík to bring home only reprimands.').

They therefore decided that Bertik would rather commute $15 \mathrm{~km}$ to our school every day and would be in a smaller social group. Bertík's brother (currently 17 years old) was the first to be adopted into a foster family at the age of about 3 years. Until then, he was placed in a children's centre. Bertík was adopted by these parents when he was around six months old. Both brothers (they have the same biological mother, different biological fathers, and their age difference is 5 years) show signs of deep 
emotional deprivation despite all the care of the adopters.

In the group of children, he was dominant, manipulative, unpopular. If there was a weak external control of the pedagogical team, he had a tendency to antisocial behaviour (for example, when Bertik was invited by a classmate to his birthday party, he stole money from him to buy a soft drink called Kofola). When I asked the other members of our pedagogical team to talk about Bertik, it was not easy (headteacher: In the conversations about Bertik, our pedagogical team is silent.). 'It is a time when the educator feels that he is constantly failing. You use all the means of education. You try to discuss, to explain, but he lies to you. Such a situation reminds me of the police during an interrogation. Eventually he cries so you become soft. And in five minutes, you are going to deal with someone who was hurt by him again.'

Bertík's parents were very worried about the freedom that the authorial reading space gives: 'We would need specific, harmless topics. If he does not mind, we will discuss it with him, a lot.'

Like all of Bertík's other activities, Bertík's texts were subjected to strong parental censorship. His parents feared that the artifact would be morally defective. At our meetings with authorial reading, Bertík read his texts correctly, but impartially, impersonally. Only here and there did his great passions appear in his content: weapons, war violence, and a hidden fascination with sexism. In the censored texts (full of neutral content), there was not much that Bertík could discover for himself. The only thing that went through the texts was Bertík's beloved fishing. I have a lot of Bertík's texts in my memory. In essence, all of them were of a template: 1) I went fishing on Saturday; 2) I caught carp/tench/pike/trout; 3) The carp/tench/pike/trout weighed and measured such and such. And then Bertík regularly defended himself that he really caught the fish and that he was not lying.

I think that authorial reading could be a extremely revealing field of possibilities for Bertík. He could find out for himself what is happening, what forces are dynamising him, and which topics are current for him. At the same time, the big pedagogical question for me is the possibilities offered by the common reality of school teaching and the power of feedback provided by younger school-age children. It is possible that if Bertík were given an authentic space and would actually write and read by himself as an author, we would probably all be surprised - myself the most. But I have never had that much courage.

\section{Preliminary Conclusions}

The article is a part of a long-term study concerning the phenomenon of experimental drama. The aim of the article was to formulate the current pedagogical experience with the discipline of authorial reading in a small-class school environment in a narrative way. The pedagogical reflection in the whole article is an interim material for formulating the nature of this emerging alternative teaching. It combines theoretical background and research data.

Research is still in the process and it is based on a long-term direct interaction in pedagogical reality. The disadvantages of this type of research and the limits of research are in the very nature of qualitative research. Conclusions cannot be generalised.

The answer to the main and minor research questions: the mentioned cases of children's authors of texts show how the actors themselves approach the authorial reading. When writing this article, it turned out that it is not possible to formulate experience with authorial reading without taking into account the personality characteristics of children and their specific manifestations. It turned out that parents also intervene in a unique way in the implementation of authorial reading in the 
environment of a small school with multiple year-group classes. Thus, pedagogical experience from authorial reading cannot be studied as an isolated phenomenon. The above examples also illustrate that authorial reading may not be the only (and guaranteed correct) way to develop the set competencies. Unlike adults, younger school children initially need some structure, such as a topic assignment. It also turns out that a topic that is lively, provocative, and less unambiguous leads to inventive texts.

From the acquired didactic experience, it is possible to mention the fact that the basis of pedagogical work with authorial reading is the gradual transfer of responsibility for the creative process to the subjects of education (texts are not a fulfilment of an external requirement but a joyful opportunity for students to express themselves). The primary goal of authorial reading at the lower basic school level must not be a 'nice text' (as a final product intended for evaluation by teachers only) but the joint discovery of individual topics worth processing, individual verification of a distinctive author's style without 'artistic' uselessness, and the development of divergent thinking. From the pedagogue's point of view, it is a matter of following the path together with the pupil: 'from where to where' the pupil develops himself in the texts. Emphasis is placed on the communicative publication of the text to others, that is, an out-loud, natural reading with the idea of the read material.

From the current technological point of view of education, in which the emphasis on student performance and efficiency dominates, it is the opposite of an effective way of pedagogical work. The problem is methodological ambiguity and the inability to make it objective. It cannot be presented by any of the available objective measures.

The cultivating of authorship (that is, the path to one's own text, to self-expression) takes time and, above all, a safe space as there is wariness about a predetermined result intended for evaluation. This somehow makes everything difficult.

The pedagogue guarantees suitable conditions for these experiments with authorial texts: a non-evaluative environment, respect for the developmental characteristics of pupils, and individual peculiarities. The role of the teacher is to further awaken mutual respect for the texts and gradually cultivate feedback so that it leads to objectivity. Related to this is the necessary pedagogical patience and tact.

\section{Contact \\ Dr Josef Nota}

University of South Bohemia in České Budějovice

Faculty of Theology

Department of Education

Kněžská 8, 37001

jnota@tf.jcu.cz 